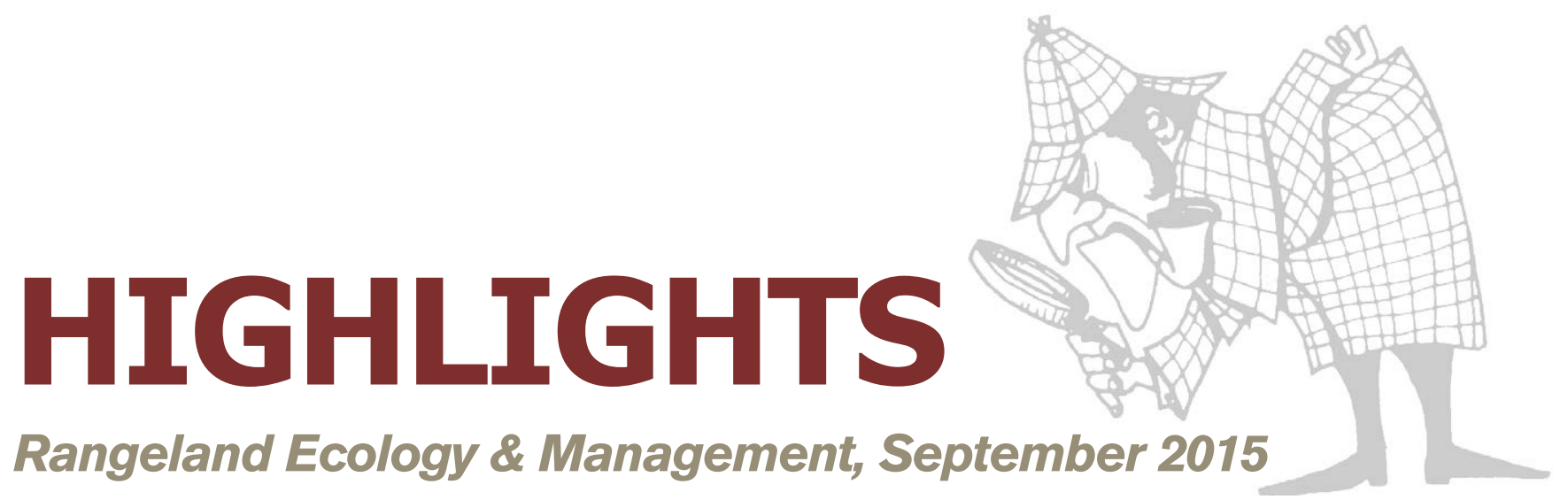

\section{Greater Sage-Grouse and Range Management: Insights from a 25-Year Case Study in Utah}

David K. Dahlgren, Randy T. Larsen, Rick Danvir, George Wilson, Eric T. Thacker, Todd A. Black, David E. Naugle, John W. Connelly, and Terry A. Messmer

The effects of rangeland management at landscape scales on sage-grouse (Centrocercus urophasianus) are not well known. We used 25 years of data across three large landscapes to assess sage-grouse population response to range management practices. The study area with prescriptive grazing and small-scale $(<500$ acre $)$ sagebrush reduction in brooding habitat increased and maintained a higher sage-grouse population for 15 years. Extreme weather then reduced the population to numbers similar to adjacent areas with less shrub removal. Small patches of sagebrush removal can benefit the sage-grouse, but it is important to maintain adequate tall sagebrush to provide nesting and winter habitat.

\section{Sustaining Working Rangelands: Insights from Rancher Decision-Making}

Leslie M. Roche, Tracy K. Schohr, Justin D. Derner, Mark N. Lubell, Bethany B. Cutts, Emily Kachergis, Valerie T. Eviner, and Kenneth W. Tate

We surveyed 507 California ranchers to learn which factors shape decision making, perspectives on management practices, and ranching information sources. Variation in ranch structure and decision making across ranching operations aligns with the suggestion from sustainability science to maintain flexibility at multiple scales. Ranchers value information from colleagues, industry organizations, Extension, and the U.S. Department of Agriculture-Natural Resources Conservation Service (USDA-NRCS). Flexible adaptive management supports the suite of economic and ecological services that rangelands can provide. Sustaining working ranches will require collaborative partnerships focused on both economic and ecological goals. Finally, ranchers perceive environmental regulations-rather than environmental drivers - as the major threats to the future of their operations.

\section{Informal Rangeland Monitoring and Its Importance to Conservation in a US Ranching Community}

Steven R. Woods and George B. Ruyle

Informal environmental monitoring can play an important role in natural resource management, but its use by US ranchers has rarely been studied. We interviewed ranchers and government agency personnel to assess informal rangeland monitoring in a rural community in Arizona. Informal monitoring was foundational to most ranchers' long-term and annual rangeland management planning, essential for adaptation to sub-yearly variations in environmental conditions, and largely compatible with natural science and complementary to formal monitoring. Closer integration of informal monitoring with formal conservation planning may improve communication and cooperation between ranchers and rangeland scientists and enable more ecologically sustainable land use.

Livestock-Mediated Dispersal of Prosopis juliflora Imperils Grasslands and the Endangered Grevys Zebra in Northeastern Ethiopia

\section{Almaz T. Kebede and D. Layne Coppock}

Honey mesquite (Prosopis juliflora) is an invasive woody plant recently observed in the Allideghi Wildlife Reserve. We determined patterns of Prosopis dispersal and establishment, impacts on grassland vegetation, and attitudes of local people toward this species. Pastoralists are now settled in the Reserve, and their livestock have imported Prosopis seeds to start a colonization process. Mature Prosopis stands dramatically reduce the cover and number of grass species. Locals view Prosopis with alarm, but coordinated control is lacking. 
Without control, the Reserve will be converted from grassland to denuded woodland, thus jeopardizing the survival of isolated populations of wild grazers.

\section{Short-Term Impacts of Tree Removal on Runoff and Erosion from Pinyon- and Juniper-Dominated Sagebrush Hillslopes}

Frederick B. Pierson, C. Jason Williams, Patrick R. Kormos, Osama Z. Al-Hamdan, Stuart P. Hardegree, and Patrick E. Clark

Tree removal is commonly prescribed in the sagebrushsteppe. We used large-plot rainfall simulations and overland flow experiments to evaluate the short-term effects of burning and tree mastication and cutting on hydrology and erosion at two woodland-encroached sagebrush sites. Fire-induced herbaceous cover reduced erosion from intercanopy sites by the second year. Cutting and placing trees into the intercanopy did not significantly affect runoff and erosion. In contrast, masticated tree debris enhanced infiltration and reduced erosion in intercanopy areas. Erosion from latesuccession woodlands is reduced primarily through recruitment of intercanopy herbaceous vegetation and ground cover.

\section{Simulating Carbon Dioxide Effects on Range Plant Growth and Water Use with GPFARM- Range Model}

\section{Zhiming Qi, Jack A. Morgan, Gregory S. McMaster, Lajpat R. Ahuja, and Justin D. Derner}

There is a need for simulation models that describe plant functional group responses to atmospheric carbon dioxide $\left(\mathrm{CO}_{2}\right)$ increase. We modified the growth rate and stomatal resistance processes in the GPFARM-Range model to respond to changes in $\mathrm{CO}_{2}$. The algorithms used are reliable and can be used to evaluate rangeland production under conditions of increased $\mathrm{CO}_{2}$. This model can be used to estimate climate change impacts on biomass. However, a predicted increase in biomass does not suggest that rangelands may sustain a higher stocking rate because of the lower digestibility of species that increase biomass at higher $\mathrm{CO}_{2}$.

\section{Challenges of Establishing Big Sagebrush (Artemisia tridentata) in Rangeland Restoration: Effects of Herbicide, Mowing, Whole-Community Seeding, and Sagebrush Seed Sources}

Martha M. Brabec, Matthew J. Germino, Douglas J. Shinneman, David S. Pilliod, Susan K. Mcllroy, and Robert S. Arkle

Efforts to restore big sagebrush are increasing in many rangelands of North America. We used a field experiment to determine how initial survival of sagebrush outplants is affected by two key management factors: sagebrush seed source and common treatments of the whole-plant community. Sagebrush seedings were not successful, probably due to drought. Longevity of sagebrush outplants was greater for the local seed source and where combinations of herbicide, mowing, and community seeding had diminished neighborhood cover. Survival of young seedlings is a demographic bottleneck for sagebrush, and continued experimentation of management factors affecting restoration success is needed.

Rangelands 37(5):208-209

doi $10.1016 /$ j.rala.2015.08.002 